\title{
ASSESSMENT OF ADULT EATING HABITS IN THE NUTRITIONAL PREVENTION OF STROKE
}

DOI: 10.36740/WLek202009203

\author{
Anna Sobalska, Katarzyna Tomczyk, Joanna Furman, Beata Łabuz-Roszak \\ DEPARTMENT OF BASIC MEDICAL SCIENCES, FACULTY OF HEALTH SCIENCES IN BYTOM, MEDICAL UNIVERSITY OF SILESIA IN KATOWICE, BYTOM, POLAND
}

\begin{abstract}
Introduction: Lifestyle modification, including changing eating habits, plays an essential role in the prevention of stroke.

The aim: The study aimed to assess the nutritional prevention of cerebrovascular diseases in adult inhabitants of Poland.

Material and Methods: The study was conducted using the author's questionnaire among 145 women and 76 men, aged 18 - 30 (53.9\%) and 50 - 70 (46.1\%) years.

Results: The following stroke risk factors were found in the examined group: overweight or obesity (46.6\%), lack of regular physical activity (48\%), smoking (33\%), hypertension (22.1\%), dyslipidemia (8.6\%), diabetes (5.9\%), and cardiac arrhythmias (6.3\%).

The younger subjects compared to older ones more often declared the daily consumption of whole-grain cereal products and vegetables, fish at least once a week, and they preferred vegetable oils. On the other hand, older subjects declared the consumption of sweets, sweet drinks, salt, and fast food less frequently than younger ones. Also, fruits were more often chosen by older people. Both groups declared similar moderate consumption of milk and dairy products with reduced fat content, lean meat, and alcohol. Only $38 \%$ of respondents considered their eating habits to be appropriate.

Conclusions: The eating habits of examined adults only partially met the recommendations regarding the nutritional prevention of stroke. In some elements, younger people were more likely to follow appropriate dietary recommendations, while older people were more appropriate in others. The education regarding the principles of the nutritional prevention of cerebrovascular diseases is still necessary and should be age-appropriate.
\end{abstract}

KEY WORDS: cerebrovascular diseases, stroke, dietary prevention, eating habits, diet

Wiad Lek. 2020;73(9 p. II):1904-1908

\section{INTRODUCTION}

Cerebrovascular diseases constitute a significant public health problem in both developing and developed countries. Just after myocardial infarction and neoplastic diseases, they are among the main causes of death [1]. Mortality due to stroke in Poland is classified as one of the highest in Europe [2,3].

The risk factors for cerebrovascular diseases, subject to modification, include arterial hypertension, ischemic heart disease, prior myocardial infarction, atherosclerotic stenoses of other arteries, heart disease (including arrhythmias), lipid metabolism disorders, hyperhomocysteinemia, diabetes, obesity, low physical activity, smoking and alcoholism [4-6]. The non-modifiable factors favoring the development of these diseases include age, sex, race, genetic factors, and a history of transient ischemic attack (TIA) or stroke [5, 7].

Changing lifestyle and diet play an essential role in the prevention of cerebrovascular diseases. A properly balanced diet can reduce the risk of developing a stroke, both in people who have not experienced symptoms of cerebral circulation failure (this is the so-called primary prevention) and in people who have had a stroke or TIA (it is the so-called secondary prevention). Prophylaxis aims to minimize the likelihood of the first or recurrent ischemic event, in particular, a stroke [8].

Fruits and vegetables are the basis of the stroke prevention diet. They are an essential source of vitamins, minerals, fiber, and antioxidants. It is recommended to eat them every day and with every meal. Each additional serving of vegetables and fruits reduces the risk of stroke by $5 \%$. Dry legumes should also be included in the diet. They are a source of minerals, B vitamins, vitamin E, and a soluble fraction of dietary fiber [9].

It is recommended that the diet consists of whole-grain products with a low glycemic index, which are the main source of complex carbohydrates and dietary fiber [10]. The type and amount of fatty acids in the diet are essential in the prevention of cerebrovascular diseases. It is recommended to limit the consumption of total fat, saturated fatty acids, and trans fatty acid isomers in favor of food products rich in unsaturated fatty acids [11].

In the anti-stroke diet, it is recommended that you choose low-fat dairy products such as skimmed cheese and milk up to $1.5 \%$ fat. Fermented dairy products are also recommended, such as yogurt, kefir, and buttermilk, since they have a positive effect on blood cholesterol levels [9].

It is recommended to eat low-fat poultry and limit the consumption of red meat, rich in methionine [9]. It is 
important to eat fish regularly, at least 2-3 times a week. Fatty sea fish are especially recommended due to the high content of omega-3 acids [12]. Table salt should be limited in the diet. Its consumption should not exceed $5 \mathrm{~g} /$ day, which corresponds to one teaspoon of salt [9].

It is crucial to choose the right heat preparation of food. Boiling, steaming, sleeve, or foil baking and stewing are recommended [9].

To reduce the risk of developing these diseases, it is crucial to maintain healthy body weight and to exercise regularly, at least 3-4 times a week. In addition to adequate nutrition and increased physical exertion, quitting smoking and limiting alcohol consumption also play a significant role [9].

The Mediterranean diet and the Dietary Approach to Stop Hypertension (DASH) diet are particularly recommended in the prevention of cerebrovascular diseases. Both diets follow these dietary recommendations. The relationship between the Mediterranean diet and the improvement in the functioning of the vascular endothelium and the lipid metabolism profile has been demonstrated. There was also a decrease in blood homocysteine concentration, a reduction in blood pressure, and an increase in insulin sensitivity [13]. On the other hand, the DASH diet, in addition to reducing arterial hypertension, has an anti-atherosclerotic effect and prevents diabetes and obesity. Thanks to the use of this diet, the incidence of stroke can be reduced by up to $27 \%$ [10].

This study aimed to assess the eating habits of adults in the nutritional prevention of stroke.

\section{MATERIALS AND METHODS}

The research was carried out in December 2018. The research tool was an original questionnaire containing 24 questions. Nine of them concerned sociodemographic data and another fifteen - eating habits. The questionnaire was posted on websites and forums concerning healthy eating and the prevention of diet-related diseases. The participation of respondents in the study was voluntary and anonymous.

Two hundred twenty-one people took part in the study, including 145 women and 76 men. The respondents were divided into two age groups. The first group consisted of people between 18 and 30 years of age $(\mathrm{n}=119 ; 53.9 \%)$, and the second group between 50 and 70 years of age $(n=102 ; 46.1 \%)$. Most of the study participants $(\mathrm{n}=185 ; 83.7 \%)$ lived in the city, while the number of rural residents was $36(16.3 \%)$. The largest percentage of respondents were people with higher education $(\mathrm{n}=102 ; 46.1 \%) .87$ respondents $(39.4 \%)$ were people with secondary education, 27 people $(12.2 \%)$ - with vocational, and 5 people (2.3\%) - with primary.

Microsoft Excel from the Microsoft Office 2007 software and STATISTICA 10.0 (Stat Soft, Poland) were used to analyze the collected data.

\section{RESULTS}

The questions included in the questionnaire concerned the nutritional status of the respondents estimated using the body mass index (BMI) (Table I), a stroke history (Table II), and the presence of comorbidities that increase the risk of cerebrovascular diseases (Table III). Nutritional habits of adults in cerebrovascular disease prevention were assessed based on questions concerning their lifestyle (Table IV) and the frequency of consumption of particular food products (Table V).

Half of the respondents had an incorrect BMI value $(\mathrm{n}=111 ; 50.2 \%)$ (Tab. I). The vast majority of respondents did not have a stroke $(n=212 ; 93.2 \%)$ (Tab. II). More than half of the respondents, i.e., 148 people (67\%), did not suffer from any diseases mentioned in the questionnaire, which would increase the risk of cerebrovascular diseases. Among the studied group, the most common were arterial hypertension $(\mathrm{n}=49 ; 22.1 \%)$, lipid metabolism disorders $(\mathrm{n}=19 ; 8.6 \%)$, cardiac arrhythmias $(\mathrm{n}=14 ; 6.3 \%)$ and diabetes $(n=13 ; 5.9 \%)$ (Tab. III).

Most of the respondents $(n=148 ; 67.0 \%)$ did not smoke. Thirty-nine people (17.7\%) declared that they smoked cigarettes habitually. Sixty-one people (27.6\%) admitted that they did not engage in physical activity. Forty-five people (20.4\%) answered that they exercised several times a month, and 20 people $(9.1 \%)$ - every day. More than $1 / 3$ of the respondents $(n=84 ; 38.0 \%)$ believed that they had healthy eating habits. 70 (31.7\%) of the respondents assessed their diet negatively, while the remaining 67 people $(30.3 \%)$ could not assess it (Table IV).

The study group showed a low consumption of wholemeal grain products: 67 people $(30.3 \%)$ consumed them every day, while 16 people (7.2\%) did not eat them at all. Higher consumption of whole grain products was observed in the younger group.

Almost half of the respondents $(\mathrm{n}=102 ; 46.1 \%)$ declared that they most often chose milk and dairy products with reduced fat content. Not much less, because 94 people (42.5\%) answered that they most often chose full-fat milk and its products. The younger group more often chose full-fat dairy products than the older group.

Fatty types of meat were chosen more often by people in the older age group. $6.8 \%$ of the respondents $(n=15)$ did not eat meat at all. Almost half of the respondents ( $\mathrm{n}=$ $100 ; 45.2 \%)$ consumed fish only a few times a month. Fish appeared on the menu once a week in 79 people (35.8\%) - more often in the group of younger people. Seventeen subjects $(7.7 \%)$ did not eat fish.

Slightly more than half of the respondents $(n=120$; $54.3 \%$ ) most often used vegetable oil - more often in the group of younger people. It was shown that more than half of the respondents $(n=129 ; 58.4 \%)$ consumed vegetables every day, while fruits were consumed every day by half of the studied group. Vegetables were eaten more often in the group of younger people, in contrast to fruits, which were more often chosen by people aged 50 - 70 .

High consumption of sweets was observed in the studied groups: 160 people $(72.4 \%)$ ate them at least once a week. Sweets appeared more frequently in the menus of younger people. It was shown that sweet drinks were most often consumed occasionally $(n=82 ; 37.1 \%)$. Comparatively, but slightly more often, they were chosen by people from the younger group 
Table I. Nutritional status of the respondents (according to the BMI value).

\begin{tabular}{cc}
\hline Body mass index $\left[\mathrm{kg} / \mathrm{m}^{2}\right]$ & $\mathbf{N}(\%)$ \\
\hline Underweight $\left[<18.5 \mathrm{~kg} / \mathrm{m}^{2}\right]$ & $8(3.6)$ \\
\hline Normal $\left[18.5-24.9 \mathrm{~kg} / \mathrm{m}^{2}\right]$ & $110(49.8)$ \\
\hline Overweight $\left[25.0-29.9 \mathrm{~kg} / \mathrm{m}^{2}\right]$ & $64(29.0)$ \\
\hline Obesity $\left[>30.0 \mathrm{~kg} / \mathrm{m}^{2}\right]$ & $39(17.6)$ \\
\hline
\end{tabular}

Table II. Characteristics of answers to the question, "Have you had a stroke?"

\begin{tabular}{cc}
\hline Prior stroke & N (\%) \\
\hline Yes & $9(4.1)$ \\
\hline No & $212(93.2)$ \\
\hline
\end{tabular}

Table III. The prevalence of selected diseases increasing the risk of cerebrovascular diseases

\begin{tabular}{cc}
\hline Disease & N (\%) \\
\hline Arterial hypertension & $49(22.1)$ \\
\hline Diabetes & $13(5.9)$ \\
\hline Dyslipidemia & $19(8.6)$ \\
\hline Cardiac arrhythmia & $14(6.3)$ \\
\hline Ischemic heart disease & $5(2.3)$ \\
\hline Prior myocardial infarction & $6(2.7)$ \\
\hline Other heart diseases & $8(3.6)$ \\
\hline Stenosis or occlusion of carotid arteries & $8(3.6)$ \\
\hline Atherosclerosis & $9(4.1)$
\end{tabular}

Table IV. The lifestyle of the studied group.

\begin{tabular}{cc}
\hline \multicolumn{2}{c}{ Smoking } \\
\hline \multicolumn{2}{c}{ N (\%) } \\
\hline Yes & $39(17.6)$ \\
\hline No & $148(67.0)$ \\
\hline Occasionally & $34(15.4)$ \\
\hline \multicolumn{2}{c}{ Physical activity } \\
\hline 5-6 times per week & $20(9.1)$ \\
\hline 3-4 times per week & $13(5.9)$ \\
\hline 1-2 times per week & $34(15.4)$ \\
\hline Several times a month & $48(21.6)$ \\
\hline Lack of any physical activity & $45(20.4)$ \\
\hline Do you eat healthily? & $61(27.6)$ \\
\hline Yes & $84(38.0 \%)$ \\
\hline No & $70(31.7 \%)$ \\
\hline I do not know & $67(30.3 \%)$ \\
\hline
\end{tabular}

$(\mathrm{n}=47 ; 39.5 \%)$. Alcohol was also consumed occasionally ( $\mathrm{n}=$ 97; 43.9\%), at a comparable level in both groups. Abstinence was declared more often by younger people $(n=17 ; 14.3 \%)$.

Slightly more than half of the respondents $(n=112$; $50.7 \%$ ) consumed fast food occasionally. This food was much less prevalent in the elderly group.
$86 \%$ of respondents $(n=190)$ used salt in a moderate, low, or very little amount of salt. Salt was more often restricted in the elderly group $(\mathrm{n}=93 ; 91.2 \%)$.

People in the 50 - 70 age group chose boiling/steaming $(\mathrm{n}=80 ; 78.4 \%)$ as the most frequently used thermal treatment of dishes, while frying/grilling was chosen more often in the group of people aged $18-30(n=82 ; 68.9 \%)$ (Table V).

\section{DISCUSSION}

In addition to smoking and low physical activity, poor nutrition is one of the main risk factors for cerebrovascular diseases. The result of an inadequate diet and increased caloric intake is excess body weight. Overweight and obesity are serious problems of the 21st century because they affect an increasing number of people and predispose to the occurrence of other risk factors for the diseases in question.

In this study, abnormal body weight was shown in a significant proportion of the respondents. This problem was also noticed by Malczyk E. et al. in a study aimed at assessing the nutritional status of university employees in Opole, which showed that overweight and obesity concerned as many as $58 \%$ of the respondents [14].

When analyzing the fat content of the diet, it was observed that the majority of respondents chose meat with the low cholesterol content. Similar results were obtained by Król E. et al., where $90 \%$ of the respondents declared the consumption of lean meat. The significant consumption of red meat by almost half of the surveyed respondents was worrying [15].

Poland is one of the countries where fish consumption is low. The results obtained confirm this conclusion, as only $11.3 \%$ of people consumed the recommended amount of fish. This fact has also been confirmed by other authors. A study by Poręba R. et al. showed that only $22.6 \%$ of people ate fish two or more times a week [16]. Similar results were obtained by Król E. et al., where $20 \%$ of people reported eating fish several times a week [15].

In this study, optimistic results were obtained for the type of fat used in the daily diet. Vegetable oil was most often chosen by the respondents. The research conducted by Poreba R. et al. showed that butter was the most frequently preferred type of fat among students from Wrocław universities [16]. A positive aspect in the area of the eating habits of the studied group was the reduction of salt in the daily diet. The same tendency was noticed in the study by Poręba R. et al., which examined the lifestyle and risk factors of cardiovascular diseases among students of the University of Wrocław [16].

The fact that alcohol consumption is common in the study group, which was also stated by other authors, raises concerns. Poręba R. et al. in the conducted study noted that nearly $90 \%$ of respondents consumed alcohol. Almost $30 \%$ of the respondents used it at least once a week. The vast majority of people consumed alcohol occasionally [16].

An essential element in the principles of healthy eating is the selection of appropriate thermal processing of food. The obtained results indicate that the most frequently used culinary techniques were frying/grilling (62.0\%) and boil- 
Table V. Comparison of eating habits in the group of younger and older people $(\mathrm{N}=221)$.

\begin{tabular}{|c|c|c|c|}
\hline & $\begin{array}{c}\text { All }(\mathrm{N}=221) \\
n(\%)\end{array}$ & $\begin{array}{c}18-30 \text { years } \\
(\mathrm{N}=119) \\
\mathrm{n}(\%)\end{array}$ & $\begin{array}{c}50-70 \text { years } \\
(\mathrm{N}=102) \\
\mathrm{n}(\%)\end{array}$ \\
\hline \multicolumn{4}{|c|}{ The frequency of consumption of whole grain products } \\
\hline Every day & $67(30.3)$ & $39(32.8)$ & $28(27.5)$ \\
\hline Less often & $138(62.5)$ & $72(60.5)$ & $66(64.7)$ \\
\hline I do not eat & $16(7.2)$ & $8(6.7)$ & $8(7.8)$ \\
\hline \multicolumn{4}{|c|}{ Fat content in the consumed milk and dairy products } \\
\hline Full fat & $94(42.5)$ & $56(47.0)$ & $38(37.2)$ \\
\hline Skimmed & $102(46.2)$ & $54(45.4)$ & $48(47.1)$ \\
\hline Without fat & $10(4.5)$ & $5(4.2)$ & $5(4.9)$ \\
\hline I do not eat & $15(6.8)$ & $4(3.4)$ & $11(10.8)$ \\
\hline \multicolumn{4}{|c|}{ The type of meat consumed } \\
\hline Lean & $188(85.1)$ & $99(83.2)$ & $89(87.3)$ \\
\hline Fat & $164(74.2)$ & $73(61.3)$ & $91(89.2)$ \\
\hline I do not eat & $15(6.8)$ & $7(5.9)$ & $8(7.8)$ \\
\hline \multicolumn{4}{|c|}{ The frequency of fish consumption } \\
\hline Several times a week & $25(11.3)$ & $11(9.2)$ & $14(13.7)$ \\
\hline Once a week & 79 (35.8) & $36(30.3)$ & $13(12.7)$ \\
\hline Several times a month & $100(45.2)$ & $58(48.7)$ & $42(41.2)$ \\
\hline I do not eat & $17(7.7)$ & $14(11.8)$ & $33(32.4)$ \\
\hline \multicolumn{4}{|c|}{ The type of fat most commonly used } \\
\hline Vegetable oil & $120(54.3)$ & $74(62.2)$ & $46(45.1)$ \\
\hline Butter / margarine / lard & $99(44.8)$ & $44(37.0)$ & $55(53.9)$ \\
\hline I do not use & $2(0.9)$ & $1(0.8)$ & $1(1.0)$ \\
\hline \multicolumn{4}{|c|}{ The frequency of consumption of vegetables } \\
\hline Every day & $129(58.4)$ & $77(64.7)$ & $52(51.0)$ \\
\hline Less often & $89(40.3)$ & $41(34.5)$ & $48(47.1)$ \\
\hline I do not eat & $3(1.4)$ & $1(0.8)$ & $2(1.9)$ \\
\hline \multicolumn{4}{|c|}{ The frequency of fruit consumption } \\
\hline Every day & $112(50.7)$ & $50(42.0)$ & $62(60.8)$ \\
\hline Less often & $109(49.3)$ & $69(58.0)$ & $40(39.2)$ \\
\hline I do not eat & $0(0.0)$ & $0(0.0)$ & $0(0.0)$ \\
\hline \multicolumn{4}{|c|}{ The frequency of consumption of sweets } \\
\hline At least once a week & $160(72.4)$ & $93(78.2)$ & $67(65.7)$ \\
\hline Several times a month & $22(10.0)$ & $10(8.4)$ & $12(11.8)$ \\
\hline Occasionally & $38(17.2)$ & $15(12.6)$ & $23(22.5)$ \\
\hline I do not eat & $1(0.5)$ & $1(0.8)$ & $0(0.0)$ \\
\hline \multicolumn{4}{|c|}{ The frequency of consumption of sweet drinks } \\
\hline At least once a week & $65(29.4)$ & $37(31.1)$ & $28(27.5)$ \\
\hline Several times a month & $22(10.0)$ & $10(8.4)$ & $12(11.8)$ \\
\hline Occasionally & $82(37.1)$ & $47(39.5)$ & $35(34.3)$ \\
\hline I do not eat & $52(23.5)$ & $25(21.0)$ & $27(26.4)$ \\
\hline \multicolumn{4}{|c|}{ The frequency of alcohol consumption } \\
\hline At least once a week & $63(28.5)$ & $31(26.1)$ & $32(31.4)$ \\
\hline Several times a month & $35(15.8)$ & $18(15.1)$ & $17(16.7)$ \\
\hline Occasionally & $97(43.9)$ & $53(44.5)$ & $44(43.1)$ \\
\hline I do not eat & $26(11.8)$ & $17(14.3)$ & $9(8.8)$ \\
\hline \multicolumn{4}{|c|}{ The frequency of consumption of fast food } \\
\hline At least once a week & $18(8.1)$ & $14(11.8)$ & $4(3.9)$ \\
\hline Several times a month & $40(18.1)$ & $32(26.9)$ & $8(7.9)$ \\
\hline Occasionally & $112(50.7)$ & $62(52.1)$ & $50(49.0)$ \\
\hline I do not eat & $51(23.1)$ & $11(9.2)$ & $40(39.2)$ \\
\hline \multicolumn{4}{|c|}{ The amount of salt consumed } \\
\hline Very big/big & $26(11.8)$ & $18(15.1)$ & $8(7.8)$ \\
\hline moderate / small / very small & $190(86.0)$ & $97(81.5)$ & $93(91.2)$ \\
\hline I do not use & $5(2.3)$ & $4(3.4)$ & $1(1.0)$ \\
\hline \multicolumn{4}{|c|}{ Type of heat treatment applied } \\
\hline Boiling / steaming & $164(74.2)$ & $84(70.6)$ & $80(78.4)$ \\
\hline Baking & $96(43.4)$ & $50(42.0)$ & $46(45.1)$ \\
\hline Stewing & $47(21.3)$ & $24(20.2)$ & $22(21.6)$ \\
\hline Frying / grilling & $137(62.0)$ & $82(68.9)$ & $55(53.9)$ \\
\hline
\end{tabular}


ing in water/steaming (74.2\%). In the study by Pudło $\mathrm{H}$. and Respondek M., 57\% of respondents also used frying [17]. The results obtained by Król E. et al. indicated that as many as $69 \%$ of respondents used frying, which is one of the inadvisable methods of cooking food. Only $31 \%$ of people cooked in water and steam [15].

This study shows a low level of physical activity in the majority of respondents. The lack of physical activity concerned even $1 / 3$ of the respondents. Similar results were obtained in the WOBASZ study (Multicenter National Population Health Survey) [18].

In recent years, there have been fewer nicotine addicts. However, the situation remains unsatisfactory. Smoking is a significant risk factor of cardiovascular diseases. Among the respondents, the percentage of smokers was 33\%, which was a similar result compared to the results obtained in the WOBASZ study, in which smokers accounted for 33.5\% [18]. The research conducted so far on lifestyle, and the assessment of eating habits shows that Polish society is particularly exposed to risk factors for cerebrovascular diseases.

\section{CONCLUSIONS}

The eating habits of the study group only partially met the recommendations for the prevention of cerebrovascular diseases. In some respects, the proper dietary recommendations were more often followed by younger people, and in others by older people. Pro-health education on the principles of proper nutrition in the field of stroke prevention is still necessary and should be conducted in a manner appropriate to the age group.

\section{REFERENCES}

1. Ryglewicz D. Udar mózgu-profilaktyka. Aktual Neurol. 2005;3(5):189193.

2. Łabuz-Roszak B, Otocka D, Bryk R, Szczeponek P, Tomczyk K. Wiedza na temat czynników ryzyka chorób sercowo-naczyniowych oraz objawów udaru mózgu wśród mieszkańców gminy wiejskiej. Wiad Lek. 2018;71(7):1214-1221.

3. Grabowska-Fudala B, Jaracz K, Górna K. Zapadalność, śmiertelność i umieralność z powodu udaru mózgu - aktualne tendencje i prognozy na przyszłość. Przegl Epidemiol. 2010;64:439-442.

4. Szczeklik A, Gajewski P. Interna Szczeklika. Kraków: Medycyna Praktyczna; 2015.

5. Pierzchała K, Łabuz-Roszak B, Gajewska A, Nowiński M, Zając M. Analiza czynników ryzyka chorób naczyniowych mózgu u chorych leczonych w pododdziale udarowym. Wiad Lek. 2006;59(1-2):44-47.

6. Baszczuk A, Kopczyński Z, Musialik K. Rozpowszechnienie nadciśnienia tętniczego na świecie iw Polsce. Forum Zaburz Metabol. 2014;5(4):141-147.

7. Czarnecka D, Zabojszcz M. Nadciśnienie tętnicze a udar mózgu. Chor Serca Naczyń. 2004;1(1):19-25.

8. Grabowska-Fudala B, Jaracz K, Górna K. Zapadalność, śmiertelność i umieralność z powodu udarów mózgu - aktualne tendencje i prognozy na przyszłość. Przegl Epidemiol. 2010;64:439-442.

9. Ciborowska H, Rudnicka A, Ciborowski A. Żywienie zdrowego i chorego człowieka. Warszawa: Wydawnictwo Lekarskie PZWL: 2014.

10. Włodarek D, Lange E, Kozłowska L, Głąbska D (eds). Dietoterapia. Warszawa: Wydawnictwo Lekarskie PZWL: 2014.
11. Kłosiewicz-Latoszek L. Zalecenia żywieniowe w prewencji chorób przewlekłych. Probl Hig Epidemiol. 2009;90(4):447-450.

12. Dutkowska A, Rachoń D. Rola kwasów tłuszczowych n-3 oraz n-6 w prewencji chorób układu sercowo-naczyniowego. Chor Serca Naczyń. 2015;12(3):154-159.

13. Bawa S, Gajewska D, Myszkowska-Ryciak J. Zastosowanie diety śródziemnomorskiej w prewencji i leczeniu zespołu metabolicznego. Kosmos - problemy nauk biologicznych. 2010;59:345-354.

14. MalczykE, Wyka J, Strojewska P. Ocena stanu odżywienia pracowników opolskiej uczelni. Bromat Chem Toksykol. 2016;3:571-575.

15. Król E, Staniek H, Przybylska A, Krejpcio Z, Olejnik D. Charakterystyka wybranych aspektów sposobu żywienia pacjentów z chorobami układu krążenia na podstawie preferencji pokarmowych. Zywn Nauka Technol Jakosc. 2006;2(47):162-170.

16. Poręba R, Gać P, Zawadzki M et al. Styl życia i czynnika ryzyka chorób układu krążenia wśród studentów uczelniWrocławia. Pol Arch MedWew. 2008;118(3):102-110.

17. Pudło H, Respondek M. Sposób żywienia i nawyki żywieniowe osób ze schorzeniami układu krążenia. Pieleg Pol. 2014;3(53):191-196.

18. Waśkiewicz A. Jakość żywienia i poziom wiedzy zdrowotnej u młodych dorosłych Polaków- badanie WOBASZ. Probl Hig Epidemiol. 2010;91(2):233-237.

\section{ORCID and contributionship}

Anna Sobalska - 0000-0003-2800-2238 ${ }^{A-D}$

Katarzyna Tomczyk - 0000-0002-1978-4920 C-D

Joanna Furman - 0000-0002-6013-5105 C-D

Beata Łabuz-Roszak - 0000-0002-9835-8240 A,C,E-F

\section{Conflict of interest}

Authors declare no conflict of interest.

\section{CORRESPONDING AUTHOR \\ Beata tabuz-Roszak}

Department of Basic Medical Sciences

Faculty of Health Sciences in Bytom,

Medical University of Silesia in Katowice,

ul. Piekarska 18, 41-902, Bytom, Poland;

tel: +48605097110

email: beatamaria.pl@hoga.pl

Received: 14.07 .2020

Accepted: 12.09 .2020

A - Work concept and design, B - Data collection and analysis, C - Responsibility for statistical analysis,

D-Writing the article, $\mathbf{E}-$ Critical review, $\mathbf{F}-$ Final approval of the article 